\title{
Efektifitas Clinical Supervision terhadap Peningkatan Class Management Abilities Guru di Sekolah Dasar
}

\author{
H. Muhsin \\ Pengawas TK/SD, Dinas Pendidikan Kabupaten Lombok Tengah - Provinsi NTB \\ Corresponding Author. Email: Muhsin_88@yahoo.com
}

\begin{abstract}
This study was to determine the effectiveness of clinical supervision to improve the class management abilities of elementary school teachers. The research method uses action research based on clinical supervision in three cycles. Implementation of clinical supervision was attended by 24 representative teachers from 10 elementary schools in the Education Office of North Batukliang District, Central Lombok. Data collection was carried out through classroom observations and class management coaching tests and was described based on the results of the teacher's mastery achievement analysis. The results showed that the percentage of completeness in each cycle was obtained $37.5 \%$ in cycle-I, $62.5 \%$ in cycle-II, and $100 \%$ for cycle-III. It can be concluded that the implementation of clinical supervision is effective to improve the ability of elementary school teachers in conducting classroom management.
\end{abstract}

\begin{abstract}
Abstrak: Penelitian ini bertujuan untuk mengetahui keefektifan dari clinical supervision untuk meningkatkan kemampuan class management guru di sekolah dasar. Metode penelitian menggunakan penelitian tindakan berbasis clinical supervision yang terdiri dari tiga siklus. Pelaksanaan clinical supervision dikuti oleh 24 orang guru yang tersebar pada 10 sekolah dasar dinas pendidikan Kecamatan Batukliang Utara, Kabupaten Lombok Tengah. Pengumpulan data dilakukan melalui observasi kelas dan tes pembinaan class management serta dideskripsikan berdasarkan skor persentase ketercapaian ketuntasan guru dalam pelaksanaan manajemen. Hasil penelitian menunjukkan bahwa diperoleh persentase Ketuntasan setiap siklus sebesar 37,5\% pada siklus I, 62,5\% di siklus II, dan $100 \%$ untuk siklus III. Berdasarkan hasil yang diperoleh dapat disimpulkan bahwa pelaksanaan clinical supervision sangat efektif untuk meningkatkan kemampuan guru sekolah dasar dalam melakukan manajemen kelas.
\end{abstract}

\section{Article History}

Received: 03-01-2021

Revised: 07-02-2021

Published: 14-04-2021

\author{
Key Words: \\ Clinical \\ Supervision, Class \\ Management, \\ Effectiveness.
}

\author{
Sejarah Artikel \\ Diterima: 03-01-2021 \\ Direvisi: 07-02-2021 \\ Diterbitkan: 14-04-2021
}

\section{Kata Kunci: \\ Clinical Supervision, \\ Class Management, \\ Efektifitas}

How to Cite: Muhsin, H. (2021). Efektifitas Clinical Supervision terhadap Peningkatan Class Management Abilities Guru di Sekolah Dasar. Jurnal Teknologi Pendidikan : Jurnal Penelitian dan Pengembangan Pembelajaran, 6(1). doi:https://doi.org/10.33394/jtp.v6i1.3625

\section{Pendahuluan}

Kondisi ideal yang diharapkan dalam pelaksanaan pembelajaran yang dilakukan oleh seorang guru adalah melaksanakan proses pembelajaran yang profesional (Ozga\& Lawn 2017; Bourke, et al., 2015; Torres \& Weiner, 2018). Minimal seperti yang telah di standarkan dalam standar proses dalam SNP. Namun, kondisi di lapangan masih jauh berbeda dari apa yang diharapkan dalam SNP tersebut. Kemampuan guru dalam melaksanakan pembelajaran masih diperlukan pembinaan sehingga hasil pembelajaran yang diharapkan dapat tercapai. Berdasarkan hasil analisis awal, kondisi ini dialami oleh guru yang ada di SD Binaan Wilayah Kec. Batukliang Utara Kab. Lombok Tengah. Kemampuan dalam melaksanakan pembelajaran masih rendah sehingga perlu dilakukan pembinan, baik oleh kepala sekolah sebagai atasan langsung maupun oleh pengawas yang menjadi binaan di sekolah. 
Kedudukan Guru dan Dosen sebagai tenaga profesional bertujuan untuk melaksanakan sistem pendidikan nasional dan mewujudkan tujuan pendidikan nasional. Berdasarkan Undang-undang Republik Indonesia No. 14 Tahun 2005 tentang Guru dan Dosen Pasal 10, dinyatakan bahwa kompetensi guru yang salah satunya meliputi kompetensi pedagogik, kompetensi kepribadian, kompetensi sosial, dan kompetensi profesional yang diperoleh melalui pendidikan profesi.

Kompetensi pedagogik adalah kemampuan guru mengelola pembelajaran peserta didik (Warren, 2018; Black \& Wiliam, 2018; Sardabi, et al., 2018). Kompetensi kepribadian adalah kemampuan kepribadian yang mantap, berakhlak mulia, arif, dan berwibawa serta menjadi teladan peserta lain (Richards, et al., 2018; Perera, et al., 2018; Kim, et al., 2018). Kompetensi profesional merupakan kemampuan guru dalam penguasaan materi pelajaran secara luas dan mendalam (Guseinova, 2018); Epstein, 2018). Kompetensi sosial adalah kemampuan guru untuk berkomunikasi dan berinteraksi secara efektif dan efisien dengan peserta didik, sesama guru, orang tua/wali peserta didik dan masyarakat sekitar (Tarman, 2018)

Sebagai pengelola pembelajaran (learning manajer), guru berperan dalam menciptakan iklim belajar yang memungkinkan siswa dapat belajar secara nyaman. Melalui pengelolaan kelas yang baik guru dapat menjaga kelas agar tetap kondusif untuk terjadinya proses belajar mengajar. Rodwell (2011) menyatakan bahwa salah satu kecendrungan yang sering dilupakan adalah hakikat pembelajaran yakni belajarnya siswa dan bukan mengajarnya guru. Klein (2018) menjelaskan prinsip-prinsip belajar dalam hubungannya dengan pengelolaan pembelajaran yakni sebagai berikut :

a) Segala sesuatu yang dipelajari oleh siswa, maka siswa harus mempelajarinya sendiri.

b) Setiap siswa yang belajar memiliki kecepatan masing-masing.

c) Seorang siswa akan belajar lebih banyak apabila setiap selesai melaksanakan tahapan kegiatan diberikan reinforcement.

d) Penguasaan secara penuh dari setiap langkan memungkinkan belajar secara keseluruhan lebih berarti.

e) Apabila siswa diberi tanggung jawab, maka ia akan lebih termotivasi untuk belajar.

Pada pelaksanakaan pengelolaan pembelajaran ada dua macam kegiatan yang harus dilakukan, yaitu megelola sumber belajar dan melaksanakan peran sebagai sumber belajar itu sendiri. Sebagai manajer, guru mempunyai empat fungsi umum (Sallis \& Jones, 2013), yaitu :

a) Merencanakan tujuan belajar.

b) Mengorganisasikan berbagai sumber belajar untuk mewujudkan tujuan belajar.

c) Memimpin, yang meliputi memotivasi, mendorong, dan menstimulasi siswa.

d) Mengawasi segala Sesuatu, apakah sudah berfungsi sebagaimana mestinya atau belum dalam rangka pencapaian tujuan.

Walaupun keempat fungsi ini merupakan kegiatan yang terpisah, namun keempatnya harus dipandang sebagai suatu lingkaran atau siklus kegiatan yang berhubungan satu sama lain. Konsep modern dari pengelolaan/manajemen kelas adalah proses mengorganisasikan segala sumber daya kelas bagi terciptanya proses pembelajaran yang efektif dan efisien. Sumber daya itu diorganisasikan untuk memecahkan aneka masalah yang menjadi kendala dalam proses pembelajaran sekaligus membangun situasi kelas yang kondusif secara terus menerus. Tugas guru di sini adalah menciptakan, memperbaiki, dan memelihara situasi kelas yang cerdas. Situasi yang cerdas itulah yang mendukung peserta didik untuk mengukur, mengembangkan, dan memelihara stabilitas kemampuan, bakat, minat, dan energi yang dimilikinya dalam rangka menjalankan tugas-tugas pendidikan dan pembelajaran. 
Berdasarkan kajian permasalahan dan alternatif solusi di atas maka dipandang perlu untuk melakukan pengontrolan/pengawasan berbasis clinical supervision terhadap standar pedagogik guru dalam melakukan manajemen kelas. Clinical supervision ini diterapkan melalui observasi kelas dan pembinaan untuk mengetahui peningkatkan kemampuan manajemen kelas guru-guru binaan di sekolah dasar.

\section{Metode Penelitian}

Konsep dasar dan prinsip-prinsip supervisi klinis memberi tekanan pada proses bantuan yang diberikan kepada guru atas dasar kebutuhan yang dirasakan dalam meningkatkan proses belajar mengajar. Peningkatan kemampuan profesional guru tersebut dimaksudkan untuk menunjang pembaharuan pendidikan serta menanggulangi degradasi proses pendidikan di sekolah dengan memperbaiki dan meningkatkan proses belajar mengajar (proses pembelajaran) di kelas.

Penelitian ini merupakan action berbasis clinical supervision untuk meningkatkan class management abilites guru. Responden penelitian sebanyak 24 orang yang berasal dari 10 Sekolah Dasar binaan yang tersebar di Kecamatan Batukliang Utara Kabupaten Lombok Tengah. Pelaksanaan clinical supervision dirancang dalam 3 siklus yang meliputi empat tahapan yakni ; (a) perencanaan, (2) tindakan, (3) pengamatan, (4) refleksi. Rancangan penelitian tindakan merujuk pada model Arikunto, S., \& Suhardjono (2006) seperti yang ditampilkan Gambar 1 berikut :

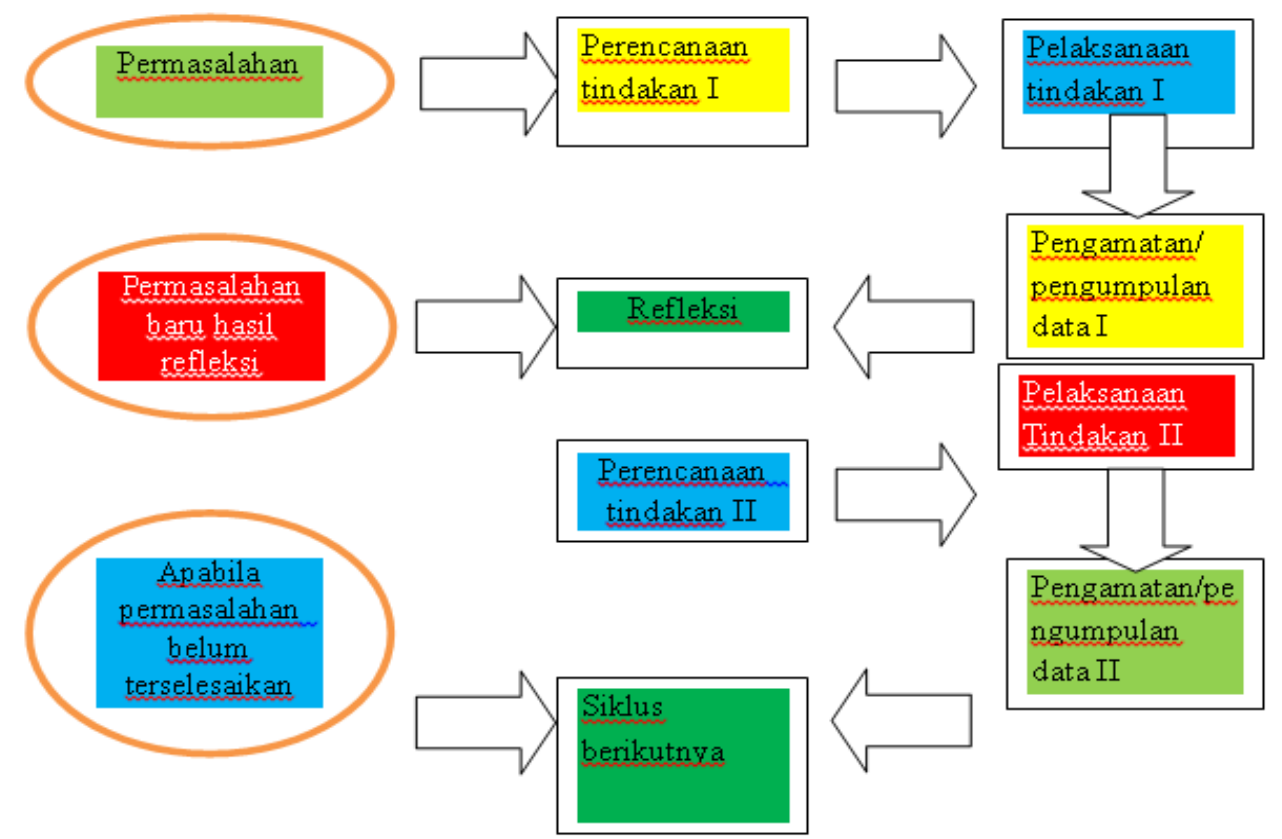

Gambar 1. Rancangan Tindakan Clinical Supervision

Deskripsi setiap tahapan tindakan clinical supervision diantaranya adalah:

1) Perencanaan: Teknik supervisi yang dilaksanakan dalam Penelitian Tindakan kepengawasan ini adalah teknik kunjungan kelas, observasi kelas, dan pertemuan individual.

2) Tindakan: merupakan pelaksanaan skenario pembelajaran yang telah direncanakan antara peneliti dan mitra peneliti. 
3) Observasi: Pada tahap ini dilaksanakan proses observasi terhadap pelaksanaan tindakan.

4) Refleksi: Tahapan ini dimaksudkan untuk mengkaji secara menyeluruh tindakan yang telah dilakukan, berdasarkan data yang telah terkumpul, kemudian dilakukan evaluasi guna menyempurnakan tindakan berikutnya.

Data riset dikumpulkan dalam penelitian ini menggunakan instrumen observasi dan tes pembinaan class management yang mengacu pada kriteria ketuntasan Nurwahida (2018) dan ditampilkan pada Tabel 1 berikut.

Tabel 1. Kriteria Ketuntasan Teachers' Performance Skor Persentase Ketuntasan (K)

\begin{tabular}{c|c} 
Skor Persentase Ketuntasan (K) & Kriteria ketuntasan \\
\hline $88 \geq K \leq 100$ & Sangat Tuntas \\
$74 \geq K \leq 87$ & Tuntas \\
$61 \geq K \leq 73$ & Kurang \\
$K \geq 60$ & Tidak Tuntas (perlu bimbingan) \\
\hline
\end{tabular}
Kriteria ketuntasan

Kriteria ketuntasan terdiri dari empat interval yakni skor $K \geq 60$ berkriteria tidak tuntas dan memerlukan bimbingan intensif dan skor $61 \geq K$ dianggap sebagai kriteria yang diharapkan (Tuntas).

\section{Hasil Penelitian dan Pembahasan}

Penelitian ini mendeskripsikan tentang kemampuan guru melakukan pengelolaan kelas setelah di-treatment dengan supervisi klinis (clinical supervison). Hasil penelitian ini menunjukkan bahwa pembinaan melalui supervisi klinis memiliki dampak positif dalam meningkatkan kemampuan guru dalam melaksanakan pembelajaran, hal ini dapat dilihat dari semakin mantapnya pemahaman guru terhadap pembinaan yang disampaikan oleh Pengawas. Terdapat peningkatan kriteria ketuntasan kemampuan guru dalam melaksanakan pembelajaran dilihat dari siklus I, II, dan III. Skor persentase dan kriteria ketuntasan ditampilkan pada Tabel 2 berikut.

Tabel 2. Persentase dan Kriteria Ketuntasan Class Management

\begin{tabular}{cccc}
\hline \multirow{2}{*}{ Siklus } & \multicolumn{3}{c}{ Ketuntasan responden (\%) } \\
\cline { 2 - 4 } & Tuntas & Tidak Tuntas & Rata-rata skor Class Management \\
\hline I & 37,5 & 62,5 & 60,04 \\
II & 62,5 & 37,5 & 70,37 \\
III & 100 & 0 & 79,79 \\
\hline
\end{tabular}

Tabel 2 menunjukkan bahwa dampak positif dari supervisi klinis pada siklus I hanya $37,5 \%$ atau 9 dari 24 guru yang tuntas. Artinya sebanyak 62,5\% guru belum maksimal dalam melakukan manajemen kelas. Selain itu, nilai rata-rata skor kemampuan manajemen kelas dari semua guru dalam hal ini sebesar $60,04 \%$. Hasil ini menunjukkan bahwa pada siklus pertama dapat dikatakan bahwa secara keseluruhan belum tuntas, karena guru yang memperoleh nilai $\geq 75$ hanya sebesar $37,5 \%$ atau baru 9 orang dari 24 guru yang tuntas, hasil ini lebih kecil dari persentase ketuntasan yang dikehendaki yaitu sebesar $74 \%$. Hal ini disebabkan karena guru masih merasa baru dan belum mengerti apa yang dimaksud dengan pembinaan melalui supervisi klinis.

Temuan pada pelaksanaan kegiatan pembinaan diperoleh informasi dari hasil pengamatan sebagai berikut:

(1) Pengawas kurang baik dalam memotivasi guru dan dalam menyampaikan tujuan pembinaan 
(2) Pengawas kurang baik dalam pengelolaan waktu

(3) Guru kurang begitu antusias selama pembinaan berlangsung.

Pelaksanaan kegiatan pembinaan pada siklus I ini masih terdapat kekurangan, sehingga perlu adanya revisi untuk dilakukan pada siklus berikutnya. Adapun rencana perbaikan yang akan diterapkan pada siklus II diantaranya yakni:

1) Pengawas perlu lebih terampil dalam memotivasi guru dan lebih jelas dalam menyampaikan tujuan pembinaan. Di mana guru diajak untuk terlibat langsung dalam setiap kegiatan yang dilakukan.

2) Pengawas perlu mendistribusikan waktu secara baik dengan menambahkan informasiinformasi yang dirasa perlu dan memberi catatan

3) Pengawas harus lebih terampil dan bersemangat dalam memotivasi guru sehingga guru bisa lebih antusias.

Hasil pelaksanaan siklus II yang ditampilkan pada Tabel 2 menunjukkan bahwa nilai rata-rata kemampuan manajemen kelas guru secara keseluruhan adalah 70,37 \% dimana skor ketuntasan mencapai $62,5 \%$ atau sebanyak 15 dari 24 orang guru yang sudah tuntas. Hasil ini menunjukkan bahwa pada siklus II ini hasil pembinaan melalui supervisi klinis telah mengalami peningkatan sedikit lebih baik dari siklus I. Adanya peningkatan kemampuan guru ini karena Pengawas telah menegaskan kembali bahwa di setiap akhir pembinaan diadakan penilaian sehingga pada pertemuan berikutnya guru lebih termotivasi untuk meningkatkan kemampuannya. Selain itu, para guru juga sudah mulai mengerti apa yang dimaksudkan dan diinginkan oleh Pengawas dalam melakukan pembinaan melalui supervisi klinis.

Temuan lain dalam pelaksanaan supervisi klinis diperoleh informasi dari hasil pengamatan bahwa masih ada beberapa guru kurang termotivasi, bingung dengan pengelolaan kelas yang baik, dan kurang baik dalam pengelolaan waktu. Temuan-temuan ini digunakan sebagai dasar untuk memperbaiki dan memaksimalkan tindakan clinical supervision untuk memaksimalkan kemampuan guru dalam melakukan manajemen kelas yang baik. Beberapa hal yang direncanakan untuk pelaksanaan tindakan pada siklus III adalah sebagai berikut:

(1) Pengawas dalam memberikan pembinaan kepada guru hendaknya dapat membuat para guru termotivasi dalam membuat program dan rencana pembelajaran.

(2) Pengawas harus lebih dekat dengan guru sehingga tidak ada perasaan takut/malu dalam diri guru terutama dalam bertanya tentang masalah yang dihadapi oleh sekolah.

(3) Pengawas harus lebih sabar dalam melakukan pembinan kepada guru terutama dalam merumuskan kesimpulan / menemukan konsep.

(4) Pengawas harus mendistribusikan waktu secara baik sehingga kegiatan pembinaan dapat berjalan efektif sesuai dengan yang diharapkan.

(5) Pengawas sebaiknya menambah lebih banyak contoh-contoh pelaksanaan pembelajaran dengan format format yang sudah distandardisasi oleh Departemen Pendidikan Nasional, dalam hal ini Lembaga Penjaminan Mutu Pendidikan ( LPMP) baik di Tingkat Provinsi maupun tingkat Pusat

Pelaksanaan tindakan pada siklus III seperti yang ditampilkan pada Tabel 2 di atas diperoleh nilai rata-rata tes formatif tentang kemampuan manajemen kelas sebesar 79,79\% sehingga dalam hal ini semua guru telah mencapai. Artinya, bahwa secara keseluruhan, guruguru yang telah mengikuti clinical supervision ini semakin mahir dalam melakukan pengelolaan kelas. Hasil pada siklus III ini juga mengalami peningkatan lebih baik dari siklus II dan I. Peningkatan hasil pembinaan pada siklus III ini dipengaruhi oleh adanya 
peningkatan kemampuan Pengawas dalam menerapkan supervisi klinis sehingga guru menjadi lebih memahami tugasnya masing-masing dan dapat meningkatkan kemampuannya dalam melaksanakan pembelajaran. Di samping itu ketuntasan ini juga dipengaruhi oleh kerja sama dari Pengawas, dan guru dalam merencanakan dan meningkatkan kinerjanya.

Pelaksanaan supervisi klinis untuk meningkatan kemampuan guru dalam manajemen kelas dalam hal ini dapat dikatakan hasilnya sangat baik. Hal itu tampak pada siklus pertama dari 24 orang guru yang ada pada saat penelitian ini dilakukan nilai rata-rata dari $60,04 \%$ meningkat menjadi 70,37 \% dan pada siklus III meningkat menjadi 79,79\%. Artinya bahwa, pembinaan Pengawas melalui supervisi klinis efektif diterapkan dalam upaya meningkatkan kemampuan guru dalam melaksanakan pembelajaran, yang berarti proses pembinaan Pengawas berhasil dan dapat meningkatkan capaian mutu sekolah khususnya di SD Binaan Wilayah Kec. Batukliang Utara Kab. Lombok Tengah. Hasil ini sesuai dengan Permen No 13 Tahun 2007 tentang kompetensi Pengawas/guru, dapat meningkatkan kinerja guru, serta dapat mengorganisasikan sekolah ke arah perubahan yang diinginkan ketercapaiannya. Hasil ini sejalan dengan temuan Veloo, et al., (2013) yang menyatakan bahwa clinical supervision dapat meningkatkan kinerja pengajaran dari guru-guru di sekolah dasar. Selain itu menurut Kolman (2018) bahwa clinical supervision juga mampu meningkatkan pemahaman guru dalam pengelolaan pembelajan.

\section{Kesimpulan}

Kesimpulan yang diperoleh dari hasil penelitian ini adalah pelaksanaan tindakan melalui supervisi klinis untuk meningkatkan kemampuan manajemn kelas khsususnya guru-guru sekolah dasar binaan dalam hal ini dinilai efektif. Pernyataan ini didukung oleh hasil penelitian yang telah dilakukan pada 24 orang guru dari 10 sekolah di kecamatan Batukliang Utara. Penelitian tindakan yang telah dilakukan berhasil mencapai ketuntasan $100 \%$ hanya dalam 3 siklus. Artinya bahwa, clinical supervision memiliki dampak positif untuk meningkatkan kemampuan guru dalam melakukan manajemen kelas.

\section{Saran}

Saran yang dapat disampaikan berdasarkan hasil penelitian ini adalah diharapkan kepada para Pengawas dapat melaksanakan pembinaan melalui supervisi klinis secara berkelanjutan.

\section{Daftar Pustaka}

Arikunto, S., \& Suhardjono, S. (2006). Penelitian tindakan kelas.

Bourke, T., Lidstone, J., \& Ryan, M. (2015). Schooling teachers: Professionalism or disciplinary power?. Educational Philosophy and Theory, 47(1), 84-100.

Black, P., \& Wiliam, D. (2018). Classroom assessment and pedagogy. Assessment in Education: Principles, Policy \& Practice, 25(6), 551-575.

Chong, W. H., Liem, G. A. D., Huan, V. S., Kit, P. L., \& Ang, R. P. (2018). Student perceptions of self-efficacy and teacher support for learning in fostering youth competencies: Roles of affective and cognitive engagement. Journal of adolescence, 68, 1-11.

Epstein, J. L. (2018). School, family, and community partnerships in teachers' professional work. Journal of Education for Teaching, 44(3), 397-406.

Guseinova, E. E. (2018). Organizational and pedagogical conditions for the development of professional competencies in the technical students' individual work through the 
example of studying the discipline" hydraulics and fluid mechanics". European Journal of Contemporary Education, 7(1), 118-126.

Kolman, J. S. (2018). Clinical supervision in teacher preparation: Exploring the practices of university-affiliated supervisors. Action in Teacher Education, 40(3), 272-287.

Klein, S. B. (2018). Learning: Principles and applications. Sage Publications.

Kim, L. E., Dar-Nimrod, I., \& MacCann, C. (2018). Teacher personality and teacher effectiveness in secondary school: Personality predicts teacher support and student selfefficacy but not academic achievement. Journal of Educational Psychology, 110(3), 309.

Makovec, D. (2018). The teacher's role and professional development. International Journal of Cognitive Research in Science, Engineering and Education, 6(2), 33.

Ozga, J. T., \& Lawn, M. A. (2017). Teachers, professionalism and class: A study of organized teachers (Vol. 42). Routledge.

Nurwahida, N. (2018). EFFORT INCREASING LEARNING RESULT OF GEOGRAPHY THROUGH PROJECT BASED LEARNING MODEL IN THE BASIC KNOWLEDGE OF MAPPING MATERIAL AT CLASS X MIPA 5 IN SMAN 2 PADANG. Jurnal Kapita Selekta Geografi, 1(3), 115-121

Perera, H. N., Granziera, H., \& Mcllveen, P. (2018). Profiles of teacher personality and relations with teacher self-efficacy, work engagement, and job satisfaction. Personality and Individual Differences, 120, 171-178.

R. Richards, K. A., Hemphill, M. A., \& Templin, T. J. (2018). Personal and contextual factors related to teachers' experience with stress and burnout. Teachers and Teaching, 24(7), 768-787.

Rodwell, G. (2011). One newspaper's role in the demise of the Tasmanian Essential Learnings Curriculum: Adding new understandings to Cohen's moral panic theory in analyzing curriculum change. Journal of Educational Change, 12(4), 441-456.

Sallis, E., \& Jones, G. (2013). Knowledge management in education: Enhancing learning \& education. Routledge.

Sardabi, N., Biria, R., \& Golestan, A. A. (2018). Reshaping Teacher Professional Identity through Critical Pedagogy-Informed Teacher Education. International Journal of instruction, 11(3), 617-634.

Torres, A. C., \& Weiner, J. (2018). The new professionalism? Charter teachers' experiences and qualities of the teaching profession. education policy analysis archives, 26, 19.

Tarman, B. (2018). The Awareness of Social Studies Teacher Candidates' Regarding Special Area Competencies and the Overlap Level of These Competencies with Social Studies Degree. Journal of Ethnic and Cultural Studies, 5(2), 16-28.

Veloo, A., Komuji, M. M. A., \& Khalid, R. (2013). The effects of clinical supervision on the teaching performance of secondary school teachers. Procedia-Social and Behavioral Sciences, 93, 35-39.

Warren, C. A. (2018). Empathy, teacher dispositions, and preparation for culturally responsive pedagogy. Journal of Teacher Education, 69(2), 169-183. 